\title{
Effects of splenic allograft in lipid profile of non-splenectomized rats: the immune and metabolic role of the "double spleen"
}

\section{Efeitos do aloenxerto esplênico no lipidograma de ratos não esplenectomizados: papel imunológico e metabólico do "baço duplo"}

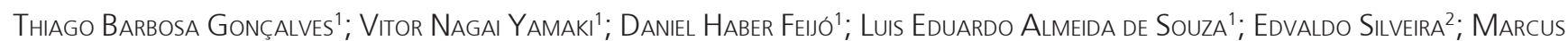
Vinicius Henriques Brito, TCBC-PA; ; Andy Petroianu, TCBC-MG ${ }^{4}$

\section{A}

\begin{abstract}
Objective: To elucidate the role of the spleen and splenic allograft in lipid control and evaluate its effect on the lipid profile of rats. Method: 32 male Wistar rats were randomly assigned into four groups: control group (1), total splenectomy group (2), splenectomy and implantation of allograft group (3) and double spleen group (4). Each group was subdivided into two subgroups: $A$ and $B$, based on the death of the animals after 30 or 120 days of monitoring. The procedures in groups 2,3 and 4 were made simultaneously, and splenectomized animals, groups 2 and 3 were donors, respectively, for the animals of groups 3 and 4 . In group 4 the spleen was preserved and the animals received implants from the spleens of rats from group 3. The regeneration of splenic tissue was evaluated by macroscopic and microscopic analyzes of the grafts and own spleens, as well as with measurements of VLDL, HDL, LDL, total cholesterol and triglycerides. Results: after 120 days, Group 4 showed levels of total cholesterol and LDL lower than the other groups. Group 1 had higher levels of lipids. Conclusion: The technique of double spleen was effective in the control of lipid metabolism, corroborating the function of the spleen as a reserve of lipids.
\end{abstract}

Key words: Spleen. Splenectomy. Transplantation. Lipid Metabolism. Cholesterol.

\section{INTRODUCTION}

$\mathrm{D}$ yslipidemia is characterized by abnormal concentrations of lipids and lipoproteins in the blood and is responsible for high morbidity and mortality in the general population due to high blood pressure and, in particular, to atherosclerotic diseases ${ }^{1}$. The Spleen, which stands out for the filtration and hematopoietic functions, also participates in metabolic control ${ }^{2}$. Persons undergoing splenectomy after splenic trauma have a higher incidence of coronary artery atherosclerosis, probably caused by lipid disorders ${ }^{3}$. Changes in lipid metabolism after splenectomy for trauma may explain the high incidence of acute myocardial infarction ${ }^{4,5}$.

The high frequency of ischemic heart disease after trauma splenectomy and the low levels of cholesterol found in patients with hypersplenism indicate the role of the spleen on lipid metabolism and on the etiology of atherosclerosis ${ }^{3}$. Patients with myeloproliferative diseases associated with hypersplenism showed a decrease in serum total cholesterol and its fraction of low-density lipoprotein $(L D L)^{6}$. After splenectomy, or when the disease was controlled, the reversal of hypocholesterolemia occurred ${ }^{2}$.

In experimental studies, total splenectomy was accompanied by high levels of cholesterol and triglycerides, with elevated LDL cholesterol 7 . Dyslipidemia Secondary total splenectomy results in higher incidence of atherosclerotic disorders $^{8}$ in rabbits submitted to total splenectomy and receiving rich-cholesterol diet.

There are a few theories to explain the possible mechanisms involved in the regulation of plasma lipids by the spleen ${ }^{7-11}$. There is evidence that there would be a splenic factor able to determine the occurrence of hypocholesterolemia in hypersplenism, the spleen being compared to a lipid reservoir, which rises in cases of hypersplenism $^{7-9}$. The splenic macrophages accumulate large amounts of fat through increased phagocytosis, with subsequent hypolipidemia. Another explanation for the lipidlowering effect would be the immune action of the mononuclear phagocyte system against structures found in the high density lipoprotein (HDL) and LDL, resulting in their clearance ${ }^{10,11}$. Caligiuri et al. ${ }^{12}$ stated that the spleen influenced lipid metabolism through the B lymphocytes,

1. Faculty of Medicine State University of Pará; 2. Department of General Pathology, Faculty of Medicine, State University of Pará; 3. Discipline of Operative Technique, Faculty of Medicine, State University of Pará; 4 Department of Surgery, Faculty of Medicine, Federal University of Minas Gerais. 
which were capable of producing anti-oxidized-LDL antibodies. This antigen-antibody complex was removed from the circulation by tissue macrophages, the splenic ones included. The spleen would participate not only in clearance of immune complexes, but also in the production of antioxidized-LDL antibodies, since it contains most of the memory $B$ lymphocytes and is the major site of antigen presentation and antibody production.

Based on such theories, in the event of asplenia after total splenectomy, there would be an increase in serum levels of certain plasma lipids, especially LDL and total cholesterol, with reduction of serum HDL. In increased splenic tissue, as in hypersplenism, the reverse would occur, ie, the decrease of serum lipids ${ }^{2}$.

It is worth noting that conservative spleen operations maintained lipid levels in the normal range. Therefore, the presence of spleen tissue, in lower amount and even ectopic, is capable of maintaining the organ functions related to the regulation of lipid metabolism. Even considering the hypothesis that the blood supply of the omentum would be less favorable than the actual irrigation of the spleen, thus decreasing the functionality of the organ, it was demonstrated that autologous transplantation of splenic tissue into the greater omentum does not cause differences in lipids².

In the literature, there are studies that discuss dyslipidemia in its general context. However, those who study the spleen function in lipid metabolism are rare. There is no consensus on the actual mechanism through which the spleen controls serum lipid levels ${ }^{2,13,14}$. The regeneration of the spleen function seems to have a direct relationship with implanted splenic mass ${ }^{15}$, so we decided to perform the allograft spleen in rats, preserving its original functioning spleen, causing the "double spleen".

This study aims to elucidate the role of the spleen in lipid control and to evaluate the effects of the "double spleen" on the lipid profile of rats.

\section{METHODS}

The animals in this study were maintained under the law for the creation and animal use (Federal Law $\mathrm{N}^{\circ}$. $11,794,2008)$, and the ethical principles of the Brazilian College of Animal Experimentation (COBEA). The project was approved by the Ethics Committee on Animal Use of the Centre of Life and Health Sciences of the State University of Pará (UEPA).

We used 32 male Wistar rats (Rattus norvegicus), with 120 days of life, from the Vivarium of the Experimental Surgery Laboratory, State University of Pará (LCE-UEPA), and kept in cages with five rats in a controlled temperature environment and 12-hour light/dark cycle. Water and feed were offered ad libitum.

The 32 rats were randomly divided into four groups ( $n=8)$ : Control Group (1) - after laparotomy there was simulated spleen manipulation of equivalent duration of the other operations. The abdominal wall of all rats was closed in two layers using continuous suture with 5-0 nylon suture; Total Splenectomy Group (2) - the stomach was tractioned out of the abdominal cavity, exposing the spleen. We performed three ligatures of the splenic vascular pedicle with 5-0 cotton suture and completed removal of the organ, which was then sliced in five segments. This was the donor group to the rats in group 3; Splenectomy and Allograft Implant Group (3) - rats in this group underwent splenectomy, after receiving the splenic segments obtained from rats in Group 2, sutured continuously on the greater omentum with 5-0 nylon suture. The stitches were alternately sutured to the spleen tissue and the omentum so as the spleen slices would be interposed by omental tissue. The spleen taken from the rats of group 3 was given to rats of group 4; Double Spleen Group (4) - the rats in this group were not splenectomized; splenic slices of Group 3 rats were implanted on the greater omentum of group 4 rats, as described in the operation of Group 3.

The animals in groups 2, 3 and 4 were operated simultaneously.

Each group was subdivided into two subgroups of four animals each: subgroup $A$ - studied 30 days after the procedure; Group B - studied after 120.

All rats were weighed and then intraperitoneally anesthetized with ketamine $(50 \mathrm{mg} / \mathrm{kg})$ and xylazine $(2.5$ $\mathrm{mg} / \mathrm{kg}$ ). The animals breathed voluntarily during procedures.

After being placed on their backs, with their limbs fixed to a surgical board $(20 \times 30 \mathrm{~cm})$, we held trichotomy of the abdominal region and skin antisepsis with polyvinylpyrrolidone (PVP) and laparotomy, then the animals were treated according with the study group.

After 30 days the animals from subgroup A all groups were again subjected to a fasting for 12 hours. Then they were weighed and anesthetized for macroscopic analysis. We collected $6 \mathrm{ml}$ of blood from the abdominal vena cava and removed the splenic fragments implanted into the omentum and the remaining spleens, if applicable. Then, the animals were euthanized with an overdose of anesthetic.

For the macroscopic study of the spleen and splenic implants, we considered normal those with color, consistency and viability (absence of necrosis). The grafts were measured.

The blood sample was used for determination of lipids. The concentrations of triglycerides, total cholesterol and HDL were performed by the enzymatic colorimetric method. The concentrations of the fractions of VLDL and LDL were calculated by the Friedewald formula.

Splenic implants and spleen were photographed and fixed in 10\% formalin. This tissue was included in paraffin and then stained with hematoxylin and eosin. 
The specimens were studied by a pathologist who did not know which group the slides belonged to. The parameters observed were hemosiderosis, extramedullary hematopoiesis, hemophagocytosis in red pulp, presence of macrophages, lymphocytes, fibrosis and areas of suppurative necrosis or liquefaction. We considered microscopically normal the splenic tissue showing no necrosis, fibrosis or cell depletion.

After 120 days from the beginning of the study, the animals of subgroup B of the four groups were fasted for 12 hours. Then they were subjected to the same protocol of the animals of subgroup $A$.

The values of total cholesterol and its fractions and triglycerides, as well as all the other numerical data, were evaluated in the two groups by the KolmogorovSmirnov (KS) test to test the Gaussian distribution of the data, and then, if the data presented Gaussian distribution, analysis of variance (ANOVA) was performed, followed by Tukey-Kramer multiple comparison test. Results were considered statistically significant if their $p$ value was less than $5 \%(p<0.05)$.

\section{RESULTS}

The total average masses of rats $(n=32)$ on the first day of the study was $247.7 \pm 44.1 \mathrm{~g}$. The average weight of the subgroups $A$ of all groups $(n=16)$ on the day of death (30 days) was $259.1 \pm 50.3 \mathrm{~g}$. For subgroups $B$ of all groups ( $n=16)$, on the day of his death (120 days) the average weight was $313.3 \pm 72.1 \mathrm{~g}$. The mean variation of the average mass of the different groups and subgroups $A$ and $B$ are shown in table 1 . Between subgroups $A$, the Control Group had the largest increase of weight, followed by the Double Spleen Group. Among the subgroups B, the Splenectomy Group was the one that had the largest increase in mass. However, in all comparisons, there was no statistical significance ( $p>0.05)$.

Rats from Double Spleen Group (4) (subgroup A) showed mean serum levels of total cholesterol and its LDL fraction superior to those presented by the other three groups (subgroup $A)(p<0.05)$. Also with regard to $L D L$, all groups were different from each other, except the Splenectomy (2) and Splenectomy and Allograft Implant (3) (Table 2) groups.
The HDL fraction of the Splenectomy Group (2) was statistically lower than the other groups (subgroup A), while the one of the Control Group was higher than the others. There were no differences with respect to serum levels of triglycerides and VLDL among all groups (Table 2).

Regarding the blood tests of rats that were killed on the 120th day after surgery (group B), all groups were different from each other with respect to total cholesterol, except the Control (1) and Total Splenectomy groups (2). Regarding the levels of LDL, the Group 2 had statistically higher levels compared with the other groups (Table 3).

There was no statistical difference in the levels of triglycerides and VLDL. Regarding the level of HDL, only the Control (1) and Double Spleen (4) groups were different (Table 3).

When comparing the different subgroups of the same group, we observed a significant difference between the subgroups of Splenectomy (2) group, whose serum total cholesterol increased over time at the expense of $\mathrm{HDL}$ and LDL $(p<0.05)$. The Double Spleen (4) group showed a significant reduction in total cholesterol levels among its subgroups $(p<0.05)$ at the expense of the LDL and VLDL fractions, while the Splenectomy + Allograft (3) group showed no difference between their subgroups.

Macroscopic analysis showed that the native spleens of rats from groups 1 and 4 were viable, presenting normal size, color and consistency, both in subgroups $A$ and $B$. As for the splenic fragments implanted into the omentum of groups 3 and 4 , in subgroups $A$ it was observed that some slices were isolated and surrounded by fibrous tissue, whereas others were united, without the omental tissue between them, with an aspect of normal spleen and with few small foci of necrosis (Figure 1). The united grafts in Group 3 were larger than those in Group 4. Few slices of grafts in Group B of these groups disappeared. Other slices were united, indurated, surrounded by abundant fibrous tissue with a spherical, tumor appearance. The average diameter of the grafts was significantly higher in Group $3(2.1 \mathrm{~cm})$ than in group $4(1.4 \mathrm{~cm})(\mathrm{p}<0.05)$.

Histopathological analysis of subgroups A and B showed that the native spleens of the rats in group 1 and 4 were normal, with no signs of fibrosis, necrosis or cell

Table 1 - Variation of the average weight gain of mice in the different groups and subgroups.

\begin{tabular}{lcc}
\hline Groups / Subgroups & A (30 days) & B (120 days) \\
\hline Control Group (1) & $+14.2 \mathrm{~g}$ & $+61.1 \mathrm{~g}$ \\
Splenectomy Group (2) & $+13.6 \mathrm{~g}$ & $+66.7 \mathrm{~g}$ \\
Splenectomy + Allograft Group (3) & $+13.4 \mathrm{~g}$ & $+63.9 \mathrm{~g}$ \\
Double Spleen Group (4) & $+13.8 \mathrm{~g}$ & $+62.2 \mathrm{~g}$ \\
\hline
\end{tabular}

$p>0.05$. 
depletion, with the presence of macrophages, lymphocytes, plasma cells, hemosiderosis, extramedullary hematopoiesis and hemophagocytosis. All allografts from subgroups A of Groups 3 and 4 presented with tumor aspect surrounded by an outer layer of fibrous tissue, low concentration of macrophages internally and a reduced core of splenic tissue between these two layers, with abundant areas of liquefaction necrosis.

In the animals of subgroups B, histopathology showed that allografts of Groups 3 and 4 had little hemosiderosis, extramedullary hematopoiesis and hemophagocytosis in the red pulp, few areas of suppurative necrosis and fibrosis, especially in Group 4. Macrophages, lymphocytes and plasma cells of allografts of both groups were similar to normal spleen.

\section{DISCUSSION}

For a long time, the functions of the spleen were ill-defined, since the absence of the spleen showed to be compatible with life. Currently, the importance of splenic tissue as a major regulator of immune and hematopoietic functions is undeniable. Well-designed studies have revealed an important splenic influence on lipid metabolism ${ }^{16}$, showing the association of splenectomized patients with various diseases such as atherosclerosis and others, caused by lipid deposits, such as Gaucher and Faber diseases ${ }^{2}$.

From the knowledge of splenic function, the option of preservation of the spleen during operative procedures increasing. Several techniques have been described as alternative methods to splenectomy: splenic suture, partial splenectomy and autologous implant, since the maintenance of splenic tissue is the only way to assure splenic function and prevent the complications of asplenia ${ }^{2}, 13$.

The mortality of the animals was lower than that found in other studies ${ }^{13}$. These deaths occurred in Group 3, undergoing splenectomy and implantation of an allograft obtained from rats from demonstrably distinct colonies. The absence of a native spleen to assist in the immune defense

Table 2 - Mean and standard error of the mean of serum total cholesterol, HDL, LDL, VLDL and triglycerides (mg/dl) after 30 days (subgroup A) of the different groups.

\begin{tabular}{lccrcc}
\hline & Total Col & \multicolumn{1}{c}{ HDL } & \multicolumn{1}{c}{ LDL } & VLDL & Triglycerides \\
\hline Control Group (1) & $69.0 \pm 6.8$ & $41.9 \pm 10.8^{+}$ & $9.7 \pm 4.1^{+}$ & $17.4 \pm 3.1$ & $87.0 \pm 13.0$ \\
Splenectomy Group (2) & $50.3 \pm 7.1^{\circ}$ & $26.4 \pm 9.7^{*}$ & $12.6 \pm 7.3$ & $11.3 \pm 8.9$ & $56.7 \pm 19.9$ \\
Splenectomy + Allograft & $57.8 \pm 10.2$ & $31.3 \pm 9.9$ & $12.2 \pm 7.4$ & $14.2 \pm 4.4$ & $71.1 \pm 17.7$ \\
Group (3) & & & & & \\
Double Spleen Group (4) & $77.7 \pm 8.8^{\#}$ & $32.3 \pm 9.7$ & $29.1 \pm 6.9^{\#}$ & $16.3 \pm 7.5$ & $81.3 \pm 15.7$ \\
\hline
\end{tabular}

Total Col.: Total Cholesterol

HDL: high-density lipoprotein

$L D L$ : low-density lipoprotein

VLDL: Very-low-density lipoprotein

o: $p<0.05$ (Group 2 compared with all other groups except Group 3)

\#: $p<0.05$ (Group 4 compared with all other groups)

*: $p<0.05$ (Group 2 compared with all other groups)

$+: p<0.05$ (Group 1 compared with all other groups)

Table 3 - Mean and standard error of the mean of serum total cholesterol, HDL, LDL, VLDL and triglycerides (mg/dl) after 120 days (subgroup A) of the different groups.

\begin{tabular}{llcrrl}
\hline & Total Col. & \multicolumn{1}{c}{ HDL } & LDL & VLDL & Triglycerides \\
\hline Control Group (1) & $70.4 \pm 105^{*}$ & $49.9 \pm 10.8^{\circ}$ & $9.6 \pm 8.1$ & $10.9 \pm 9.3$ & $54.3 \pm 11.8$ \\
Splenectomy Group (2) & $75.7 \pm 11.1^{*}$ & $38.8 \pm 9.9$ & $24.4 \pm 5.3^{+}$ & $12.5 \pm 8.4$ & $62.7 \pm 17.3$ \\
Splenectomy + Allograft & $56.0 \pm 7.2$ & $36.8 \pm 7.9$ & $9.1 \pm 7.4$ & $10.1 \pm 7.1$ & $50.5 \pm 12.9$ \\
Group (3) & & & & & \\
Double Spleen Group (4) & $46.5 \pm 14.8$ & $29.5 \pm 4.7^{*}$ & $8.2 \pm 7.1$ & $8.8 \pm 6.5$ & $44.0 \pm 11.0$ \\
\hline
\end{tabular}

Total Col.: Total Cholesterol

HDL: high-density lipoprotein

$L D L$ : low-density lipoprotein

VLDL: Very-low-density lipoprotein

*: P> 0:05 (Only groups 1 and 2 are no different, other differ)

o: $p<0,05$ (Group C compared with Group 4)

+ : $P<0,05$ (Group $C$ compared with all other groups). 


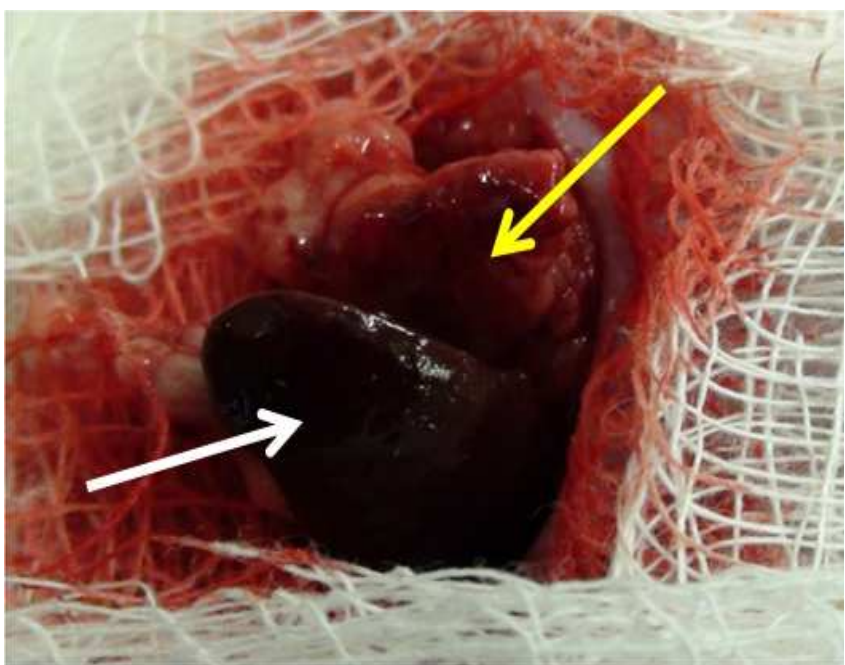

Figure 1 - Macroscopic appearance of the sliced splenic graft implanted into the greater omentum after 30 days (yellow arrow) and of the native spleen (white arrow) of a rat of subgroup $A$ of the Double Spleen group.

of the body contributed to the high mortality observed in this group ${ }^{17}$.

There was a high incidence of tail necrosis in rats in Group 2, undergoing only splenectomy, killed at 120 days of follow-up. This necrosis is commonly associated in experimental animals to infection by Streptococcus, which may have been facilitated by the state of asplenia, since the splenic immune functions in this group were deleted. The fact that this disease has not affected Group 3, which also underwent splenectomy, shows that, after the period of splenic allograft regeneration, as demonstrated in the microscopic analysis, immune functions were restored by the implant ${ }^{17,18}$

In subgroup A, we observed higher levels of total cholesterol and LDL in the Double Spleen group (4). This result suggests that 30 days were insufficient to complete organ regeneration, which requires approximately 58 weeks for functional reestablishment ${ }^{15,19}$. No being able to play it immune and metabolic role, the allograft created a situation of immune stress, acting as a foreign body, so that the native spleen performed greater immune function against the graft, leaving in the background its role in lipid metabolism. Therefore, both spleens were in an anomalous situation of hyper-functionality, the first attacking the organism, the second self-defending it.

As for the levels of $\mathrm{HDL}$, the lowest values were found in group 2, of both subgroups, agreeing with a similar study². Decreased HDL can happen due to the concentration of cholesterol contained in each type of chow used.

After 120 days postoperatively, there was improvement in the levels of total cholesterol and fractions in the Spleen Double Group, with inversion in the standard lipid profile of animals. After regeneration, allograft stopped working as a foreign body, reverting the situation of immunological stress, and aided the native spleen in the clearance of plasma lipids. In addition, the Splenectomy group had higher levels of LDL, in agreement with other studies $2,7,8$.

There are numerous explanations for this phenomenon. The results of this study confirm the hypothesis proposed by other authors ${ }^{7-9}$ comparing the spleen to a lipid reservoir, where the splenic macrophages accumulate large amounts of fat through increased phagocytosis with subsequent hypolipidemia.

It is known that the maintenance of implanted autogenous splenic tissue prevents complications of splenectomy ${ }^{13}$. However, doubling the amount of splenic tissue in the body had not yet been described. The technique of Double Spleen, though initially triggering an immune stress situation where metabolic functions are not a priority, in the long term proved to be effective in restructuring and rebuilding of the metabolic functions of the spleen, with considerable improvement in the lipid profile of animals. These results, together with the histopathological analysis, are indicative of a metabolic functioning more improved than in the other animals of the study, since it obtained the lowest cholesterol levels after 120 days.

Some experimental transplantation studies ${ }^{20,21}$ have described oral administration of spleen cells along with the transplanted tissue in order to reduce the rejection, as well as the amount of immunosuppressive agents being used. This makes it possible to justify the evolution of better lipid profile in Group 4.

The technique of Double Spleen generates a new situation of functional overload and, in the early days, the spleen starts to work under conditions of intense immune stress. Under these conditions, the metabolic functions are no longer essential and spleens start acting unpredictably. However, after the complete regeneration of splenic grafts, metabolic functions improve.

The technique of Double Spleen showed a significant improvement in the standard lipid profile of the study animals, demonstrating that the splenic tissue overload enhanced the metabolic function of the organ, thus confirming the theory of the spleen as a lipid reservoir. 


\section{R E S U M O}

Objetivo: Este estudo objetiva elucidar o papel do baço e do aloenxerto esplênico no controle lipídico e avaliar seu efeito no lipidograma de ratos. Método: Foram distribuídos aleatoriamente 32 ratos machos da linhagem Wistar em quatro grupos: grupo controle (1), grupo esplenectomia total (2), grupo esplenectomia e implante de aloenxerto (3) e grupo baço duplo (4). Cada grupo foi subdividido em dois subgrupos: A e B, com base na morte dos animais após 30 ou 120 dias de acompanhamento. Os procedimentos nos animais dos grupos 2, 3 e 4 foram feitos simultaneamente, sendo que os animais esplenectomizados, grupos 2 e 3, foram doadores, respectivamente, para os animais dos grupos 3 e 4 . No grupo 4 preservou-se o baço dos animais e implantou-se outro baço oriundo dos ratos do grupo 3. A regeneração do tecido esplênico foi avaliada por análises macro e microscópicas dos enxertos e dos baço próprios, bem como dosagens de VLDL, HDL, LDL, colesterol total e triglicérides. Resultados: O Grupo 4 apresentou, após 120 dias, níveis de LDL e colesterol total inferiores aos demais grupos. O Grupo 1 apresentou os níveis de lipidograma mais elevados. Conclusão: A técnica do baço duplo foi eficaz no controle do metabolismo lipídico, comprovando a função do baço como reserva de lipídios.

Descritores: Baço. Esplenectomia. Transplante. Metabolismo dos lipídeos. Colesterol.

\section{REFERENCES}

1. Franca $E$, Alves JGB. Dislipidemia entre crianças e adolescentes de Pernambuco. Arq Bras Cardiol. 2006;87(6):722-7.

2. Petroianu A, Veloso DFM, Costa GR, Alberti LR. Efeitos de operações sobre o baço no lipidograma de ratas. Rev Assoc Med Bras. 2006;52(1):56-9.

3. Fatouros M, Bourantas K, Bairaktari E, Elisaf M, Tsolas O, Cassioumis D. Role of the spleen in lipid metabolism. Br J Surg. 1995;82(12):16757.

4. Robinete CD, Fraumeni JF Jr. Splenectomy and subsequent mortality in veterans of the 1939-45 war. Lancet. 1977;16(8029):127-9.

5. Petroianu A, Veloso DFM, Alberti LR. Alterações do lipidograma após esplenectomia total, esplenectomia subtotal e auto-implante esplênico em ratas. JBT J Bras Transpl. 2008;11(4):1004-7.

6. Gilbert HS, Ginsberg H, Fargerstrom R, Brown WV. Characterization of hypocholesterolemia in myeloproliferative disease. Relation to disease manifestations and activity. Am J Med. 1981;71(4):595602.

7. Aviram M, Brook JG, Tatarsky I, Levy Y, Carter A. Increased lowdensity lipoprotein levels after splenectomy: a role for the spleen in cholesterol metabolism in myeloproliferative disorders. Am J Med Sci. 1986:291(1):25-8

8. Asai K, Kuzuya M, Naito M, Funaki C, Kuzuya F. Effects of splenectomy on serum lipids and experimental atherosclerosis. Angiology. 1988;39(6):497-504.

9. Schmidt HH, Wagner $\mathrm{S}$, Manns $\mathrm{M}$. The spleen as a storage pool in lipid metabolism. Am J Gastroenterol. 1997;92(6):1072

10. Goldfarb AW, Rachmilewitz EA, Eisenberg S. Abnormal low and high density lipoproteins in homozygous beta-thalassaemia. $\mathrm{Br} J$ Haematol. 1991;79(3):481-6.

11. Le NA, Gibson JC, Rubinstein A, Grabowski GA, Ginsberg HN. Abnormalities in lipoprotein metabolism in Gaucher type 1 disease. Metabolism. 1988;37(3):240-5

12. Caligiuri G, Nicoletti A, Poirier B, Hansson GK. Protective immunity against atherosclerosis carried by $\mathrm{B}$ cells of hypercolesterolemic mice. J Clin Invest. 2002;109(6):745-53.

13. Paulo ICAL, Paulo DNS, Silva AL, Foletto RM, Colnago GL, Vargas PM. Níveis de lípides plasmáticos em ratos submetidos à esplenectomia total, ligadura simultânea dos vasos esplênicos e à esplenectomia subtotal com preservação do pólo inferior. Rev Col Bras Cir. 2005;32(5):229-36.

14. Paulo ICAL, Silva AL, Piras C, Ramos BF, Zanetti FB, Paulo DNS Aspectos morfológicos e funcionais dos autoimplantes esplênicos em ratos tratados com oxigenio hiperbárico. Rev Col Bras Cir 2010;37(3):226-33.
15. linuma $H$, Okinaga K, Sato S, Tomioka M, Matsumoto K. Optimal site and amount of splenic tissue for autotransplantation. J Surg Res. 1992;53(2):109-16.

16. Simões FC, Marques RG, Diestel CF, Caetano CER, Dinis APG, Horst NL, et al. Lipidic profile among rats submited to total splenectomy isolated or combined with splenic autotransplant. Acta Cir Bras. 2007;22(Suppl 1):46-51.

17. Torres OJM, Macedo EL, Picianni ERG, Nunes PMS, Costa JVG, Carvalho $A B$, et al. Estudo histológico da regeneração esplênica de ratos submetidos à esplenectomia subtotal. Acta Cir Bras. 2000;15(2):107-13.

18. Marques BMFPP. Influencia das lesões de caudofagia na fase de terminação sobre o desempenho zootécnico, sanitário e condenações ao abate de suínos [dissertação]. Rio Grande do Sul: Universidade Federal do Rio Grande do Sul, Faculdade de Veterinária; 2010.

19. Tavassoli M, Ratzan RJ, Crosby WH. Studies on regeneration of heterotopic splenic autotransplants. 1973;41(5):701-9.

20. Paulo ICAL, Paulo DNS, Kalil M, Guerra AJ, Guerzet EA, Silva AL. Lípides plasmáticos em ratos após cirurgia esplênica - efeito de dois tipos de dieta. Rev Assoc Med Bras. 2007:53(2):171-7.

21. Dettino AL, Duarte AJ, Sato MN. Induction of oral tolerance and the effect of interleukin-4 on murine skin allograft rejection. Braz J Med Biol Res. 2004;37(3):435-40

Received on 15/11/2012

Accepted for publication 10/01/2013

Conflict of interest: none.

Source of funding: none.

\section{How to cite this article:}

Gonçalves TB, Yamaki VN, Feijó DH, Silveira E, Brito MVH, Petroianu A Effects of splenic allograft in lipid profile of non-splenectomized rats: the immune and metabolic role of the "double spleen". Rev Col Bras Cir. [periódico na Internet] 2014;41(2). Disponível em URL: http:// www.scielo.br/rcbc

\section{Address for correspondence:}

Vitor Nagai Yamak

E-mail: vitoryamaki@gmail.com 